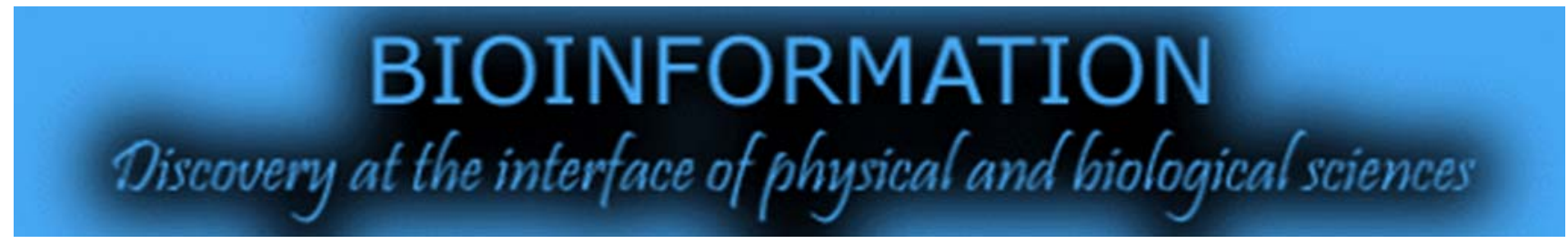

\title{
The protection role of heat shock protein 70 (HSP- $70)$ in the testes of cadmium-exposed rats
}

\author{
Manar E Selim ${ }^{1,2 *}$, El Hamidi A Rashed1', Nadia A Aleisa1, Maha H Daghestani1
}

1Zoology Department, College of Science, King Saud University, Saudi Arabia, Riyadh-11451, KSA; ${ }^{2 Z}$ oology Department, Ain Shams University, Cairo, Egypt; Manar E.Selim - Email: manares1@hotmail.com; Phone: +966 (0) 56 3588453; * Corresponding author

Received December 26, 2011; Accepted December 28, 2011; Published January 06, 2012

\begin{abstract}
:
Cadmium (Cd) is an environmental carcinogenic pollutant known to inactivate several proteins involved in DNA repair systems while at the same time creating an oxidative stress that can result in additional DNA lesions. The testis and the lung are the target organs for cadmium carcinogenesis. Increased production of oxidants in vivo can cause damage to intracellular macromolecules such as DNA, proteins and lipids, which in turn lead to oxidative injury. So, this investigation aimed to evaluate the protective role of L-Carnitine through up regulation of HSPs against DNA damage induced by cadmium chloride. The current study was carried out on forty adult male rats, each with average weight $220-250 \mathrm{~g}$., were divided into 4 equal groups. $1^{\text {st }}$ group was received saline solution (0.5 ml/100 g body weight) and kept as control. 2nd group was received 500mg / $\mathrm{kg}$ body weight L-Carnitine intraperitoneally (IP). $3^{\text {rd }}$ group was administered $1.2 \mathrm{mg}$ cadmium chloride IP. $4^{\text {th }}$ group was received both cadmium chloride and L-Carnitine simultaneously. The comet assay parameters showed significantly increased HSP70 and DNA damage in testis cells after 10 and 56 days in the third group. Meanwhile, HSP70 showed significantly decreased levels after 10 days and 56 days in the fourth group after L-Carnitine treatment simultaneously with cadmium chloride. The results of the present study demonstrate a damaging effect of cadmium chloride on DNA of the testis cells (with low stress response). This damaging effect increases the synthesis of HSP70 that upregulated by L-Carnitine treatment and showed ameliorative effect of the cells for recovery.
\end{abstract}

Keywords: Testis, Hsp70, Cadmium, L-Carnitine

\section{Background:}

Cadmium, is an ubiquitous environmental contaminant, damages several major organs in humans and other mammals. The molecular mechanisms for damage are not known. At high doses ( $5 \mathrm{mg} / \mathrm{kg}$ cadmium chloride or higher), testicular damage in mice, rats, and other rodents includes interstitial edema, hemorrhage, and changes in spermatogenesis with necrosis that is evident by $48 \mathrm{hr}$ [1]. Cadmium is a highly reactive metal, adversely affecting many mammalian organ systems, including kidney, liver, lung, pancreas, testis, prostate, ovary, and placenta [2]. In humans, chronic environmental and occupational exposure causes severe bone and kidney damage and acute occupational exposure from cadmium fumes causes pulmonary edema [3]. Cadmium-induced testicular damage in mice, rats, and other rodents includes interstitial edema and hemorrhage, accompanied by damage to seminiferous tubules affecting sperm cells and their precursors [4]. Testicular endothelial tissue is a primary target of systemically administered cadmium, with edema detected $1 \mathrm{~h}$ after an injection of a very high dose of $\mathrm{CdCl}_{2}(10 \mathrm{mg} / \mathrm{kg}$, SC) in rats [5]. At lower doses, however, peritubular cells and the seminiferous epithelium have been shown to be primary targets [6]. For example, a single low dose of $\mathrm{CdCl}_{2}(1 \mathrm{mg} / \mathrm{kg}$, I.P) in rats caused failure of spermiation and fragmentation of basal Sertoli cell junction, microfilament bundles in the absence of edema or necrosis [7]. Similarly, a study investigating Sertoli cell junctional dynamics in rats using a moderate dose of $\mathrm{CdCl}_{2}(3$ $\mathrm{mg} / \mathrm{kg}, \mathrm{I} . \mathrm{P})$ found that damage to Sertoli cell barriers occurred 
prior to damage to vascular endothelial barriers [8]. Therefore, seminiferous epithelial toxicity is not necessarily a consequence of vascular damage. A disruption of cell-to-cell endothelial and epithelial junctions, possibly due to disruption of the internal cytoskeleton, has been proposed as a mechanism for cadmium toxicity in the testis $[8]$ and other organ $[9,10]$.

L-Carnitine (L- $\beta$-hydroxy- $\gamma-\mathrm{N}$-trimethylaminobutyric acid (LC) is present in the free or acy L-Carnitine form in the plasma [8, 9]. LC plays an important role in lipid metabolism; it acts an essential cofactor for the â-oxidation of fatty acids by facilitating the transport of long-chain fatty acids across the mitochondrial membrane as acyL-Carnitine esters. It can activate carnitine palmityl transferase-1 (CPT-1), the key enzyme in fatty acid oxidation [11]. Furthermore, because LC shuttles acetyl groups from inside to outside the mitochondrial membrane, it increases the CoA-SH/acetyl-CoA ratio in the mitochondrion by forming Acetyl L-Carnitine (ALC) with the help of carnitine acetyltransferase (CAT) [12], whose activity relieves inhibition of the PDH complex and increases glycometabolism [13, 14]. According to a previous study, significantly reduced lactate plasma levels suggested that LC can also stimulate the activity of pyruvate dehydrogenase (PDH) [15].In addition, LC was defined as a biomarker to assess the function of the mitochondria [16]. Evidences showed that a combination of nutrients, including LC, can improve mitochondrial dysfunction in the liver of type 2 diabetic in rats [17]. Recently, Karanth et al. [18] proposed that LC supplements enhanced the activity of mitochondrial enzymes and the respiratory chain enzymes. However, a recent study showed that LC played a role in reducing steatosis in patients with hepatitis $C$ treated with alpha-interferon (IFN) alpha and ribavirin [19]. LC supplements in patients with NASH (non-alcoholic steatohepatitis) greatly improved glucose plasma levels, lipid profiles and histological manifestations [20]. Another author mentioned that L-Carnitine had a significant effect on improving semen parameters and seems to be an appropriate choice for idiopathic infertile men [21]. Carnitine ( $\beta$-hydroxy- $\gamma-$ $N$-trimethylaminobutyric acid) is widely distributed in food from animal's sources but there is limited availability in plants [22]. In humans, $75 \%$ of carnitine is obtained from the diet [23]. L-Carnitine (the biologically active stereoisomer) is absorbed from foods via both active and passive transport across enterocyte (intestinal cell) membranes [24]. The bioavailability of L-Carnitine varies due to dietary composition. Bioavailability of L-Carnitine in individuals such as vegetarians who are adapted to low-carnitine diets is higher ( $66 \%$ to $86 \%$ of available carnitine) than regular red-meat eaters adapted to highcarnitine diets (54\% to $72 \%$ of available carnitine) [25]. Carnitine not obtained from food is synthesized endogenously from two essential amino acids, lysine and methionine. This occurs in kidney, liver and brain [26]. Cardiac and skeletal muscle, harboring the highest concentrations, cannot synthesize carnitine and so must acquire carnitine from plasma. Unabsorbed L-Carnitine is mostly degraded by microorganisms in the large intestine [24]. Almost all carnitine (99\%) is intracellular [26]. Carnitine influences carbohydrate metabolism. Aberrations in carnitine regulation are implicated in complications of diabetes mellitus, hemodialysis, trauma, malnutrition, cardiomyopathy, obesity, fasting, drug interactions, endocrine imbalances and other disorders. Understanding the potential of LC to upregulate Hsp in injured testis tissue would be highly valuable, since these proteins could attenuate the antioxidant tolerance in this type of testis. Since the first report [27] on the heat-induced appearance of chromosomal puffing in salivary gland tissue of Drosophila busckii in 1962, a new research domain has been intensively explored. This research resulted in the discovery of a large number of related proteins and their physiological role in many prokaryotic and eukaryotic organisms, tissues, and individual cells and at the level of subcellular structures. These proteins were originally called "heat shock proteins" [28], because they were discovered in salivary glands and other tissues of Drosophila melanogaster recovering from a so-called transient sublethal heat shock, during which body temperature was increased $\sim 5^{\circ} \mathrm{C}$ above normal body core temperature [29]. Such a mild heat shock elicited a heat shock response, characterized by the synthesis of new heat shock proteins normally almost absent in tissues of adult animals and by an increased synthesis of constitutively present or cognate heat shock proteins. This event was followed by a transient increased tolerance to high, normally lethal temperatures (thermotolerance). Later it was found that not only the tolerance to enhanced temperature increases, but also the resistance toward other events like hypoxia, ischemia, inflammation, and exposure to such cellular toxins as heavy metals, endotoxins, and reactive oxygen species (cross-tolerance), all imposing serious stress upon tissues and their composing cells [29]. Although the physiological role of heat shock proteins and their protective potential under pathophysiological circumstances have been studied in detail in animal models, knowledge of the role and effects of these proteins in humans is still limited. Where possible the relevance of the observations for the human situation is discussed.

The aim of the present study was to explore the preventive and therapeutic effect of LC on testis toxicity induced by cadmium chloride with regard to DNA damage. We also intended to determine the protective role of HSP70 against cadmium that may provide theoretical evidence for LC as a clinical therapy for testis injury.

\section{Methodology:}

The current study was carried out on 40 male Wistar rats. Their average weight was 200-250 g. They were 12-16 weeks old. They were housed in a controlled environment and get free access to water ad labitum. Rats were divided into four groups (10 rats each) according to the following experimental design. Group I: was received saline solution $(0.5 \mathrm{ml} / 100 \mathrm{~g}$ body weight $)$ and kept as control. Group II: was received 500mg / kg body weight L-Carnitine IP [30]. L-Carnitine was obtained from the Sisco Research Laboratories (P) Ltd, Mumbai, India. Group III: was administered IP $1.2 \mathrm{mg}$ cadmium chloride (BDH Chemicals Ltd, Poole) that was dissolved in $0.9 \%(\mathrm{w} / \mathrm{v}) \mathrm{NaCl}$ to give a solution containing $0.12 \mathrm{mg} \mathrm{CdCl} / 0.1 \mathrm{ml}$. The solution was sterilized by autoclaving at $13 \mathrm{lb} / \mathrm{in}^{2}$ for $15 \mathrm{~min}$; the $\mathrm{pH}$ after autoclaving was 6.5 [31]. Group IV: was treated simultaneously with LCarnitine (the same dose as mentioned for group II) and cadmium chloride (the same dose as in group III). 5 rats/ group were killed, 10 days post treatment and other five rats/group were sacrificed, 56 days post treatment and the testes of experimental groups were collected. The testes were frozen till measure the DNA damage by comet assay and the level of heat shock protein by ELISA Technique. 


\section{Comet Assay}

$1 \mathrm{~g}$ of crushed samples were transferred to $1 \mathrm{ml}$ ice-cold PBS. This suspension was stirred for $5 \mathrm{~min}$ and filtered. Cell suspension $(100 \mu \mathrm{l})$ was mixed with $600 \mu \mathrm{l}$ of low-melting agarose (0.8\% in PBS). $100 \mu \mathrm{l}$ of this mixture was spread on precoated slides. The coated slides were immersed in lyses buffer (0.045 M TBE, pH 8.4, containing 2.5\% SDS) for $15 \mathrm{~min}$. The slides were placed in electrophoresis chamber containing the same TBE buffer, but devoid of SDS. The electrophoresis conditions were $2 \mathrm{~V} / \mathrm{cm}$ for $2 \mathrm{~min}$ and $100 \mathrm{~mA}$. Staining with ethidium bromide $20 \mu \mathrm{g} / \mathrm{ml}$ at $4^{\circ} \mathrm{C}$. The observation was with the samples still humid, the DNA fragment migration patterns of 100 cells for each dose level were evaluated with a fluorescence microscope (With excitation filter 420-490nm [issue $510 \mathrm{~nm}])$. The comets tails lengths were measured from the middle of the nucleus to the end of the tail with 40x increase for the count and measure the size of the comet. For visualization of DNA damage, observations are made of EtBr-stained DNA using a 40x objective on a fluorescent microscope [32].

Although any image analysis system may be suitable for the quantitation of SCGE data, we use a Comet 5 image analysis software developed by Kinetic Imaging, Ltd. (Liverpool, UK) linked to a CCD camera to assess the quantitative and qualitative extent of DNA damage in the cells by measuring the length of DNA migration and the percentage of migrated DNA. Finally, the program calculates tail moment. Generally, 50 to 100 randomly selected cells are analyzed per sample.

\section{Measurement of HSP-70}

The testes were homogenated, to investigate HSP70 using Enzyme-linked immunosorbent assay Kit (E90873Ra, UscanUSA).

\section{Statistical Analysis}

The data were expressed as the mean \pm S.E. and were analyzed by means of one-way analysis of variance (ANOVA). Statistical evaluation of data was done following Student's $t$-test. A difference was considered significant at $p<0.05$.

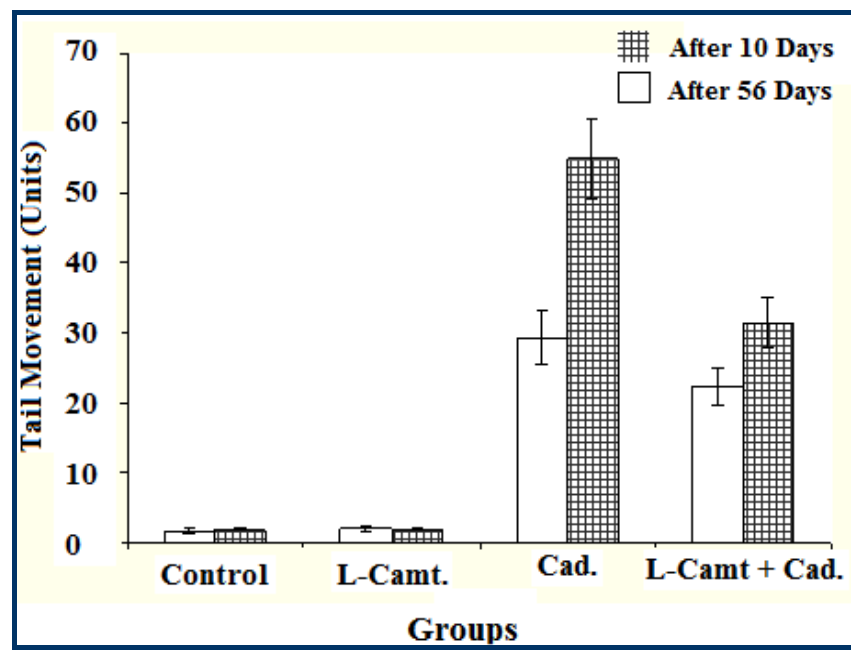

Figure 1: Demonstrates that cadmium chloride exposure produce significant elevations of tail moment in compare with control group. However, L-Carnitine induces non significant change of tail moment. Synchronized administration of cadmium chloride and L-Carnitine evokes significant reduction of tail moment in compare with cadmium chloride group.

\section{Results:}

Comet assay in different groups

As shown in Table 1 (see supplementary material)and Figure 1, no remarkable alterations of tailed cells, tail length, tail DNA $\%$ and tail moments were noticed in L-Carnitine treated group through the whole experiment as compared with control group $(3.6 \pm 1.1-3 \pm 0.92,96.4 \pm 4.28-97 \pm 2.9, \quad 1.42 \pm 0.4-1.38 \pm 0.2, \quad 1.34 \pm 0.3-$ ,1.39 $\pm 0.4-1.8 \pm 0.2 \quad$ vs $3 \pm 1.2-2.8 \pm 0.5, \quad 97 \pm 2.8-97.2 \pm 3.9, \quad 1.26 \pm 0.2-$ $1.38 \pm 0.3,1.2 \pm 0.2-1.27 \pm 0.4,1.54 \pm 0.3-1.77 \pm 0.1)$, but $\mathrm{CdCl}_{2}$ treated rats (on days 10 and 56) induced significant elevations of tailed cells, tail length, tail DNA \%, tail moments as compared to control group (15.32 $\pm 4.7-22 \pm 3.6,84.68 \pm 3.2-78 \pm 4.0,4.98 \pm .0 .2-$ $7.41 \pm 1.42,5.17 \pm 1.21-7.38 \pm 1.5,29.26 \pm 3.9-54.87 \pm 5.7,27$ vs $3 \pm 1.2$ $2.8 \pm 0.5, \quad 97 \pm 2.8-97.2 \pm 3.9, \quad 1.26 \pm 0.2-1.38 \pm 0.3, \quad 1.2 \pm 0.2-1.27 \pm 0.4$, $1.54 \pm 0.3-1.77 \pm 0.1)$. Synchronized exposure to cadmium chloride and L-Carnitine induce significant reduction in tailed cells, tail length, tail DNA \%, tail moments as compared to cadmium chloride treated group (13.6 $\pm 4.2-17 \pm 3.5,86.4 \pm 4.7-83 \pm 3.5$, $4.73 \pm 0.3-5.67 \pm 1.33 ， 4.69 \pm 1.0-5.53 \pm 0.3 ， 22.24 \pm 2.7-31.40 \pm 3.5$ vs

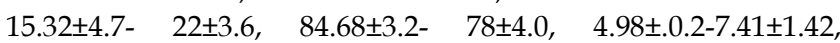
$5.17 \pm 1.21-7.38 \pm 1.5, \quad 29.26 \pm 3.9-54.87 \pm 5.7, \quad 27.97 \pm 3.7-42.11 \pm 3.4)$. Figure 3 demonstrated the effect of cadmium chloride and LCarnitine on DNA damage using Comet Assay, the white arrows pointed to comet tail of affected nuclei.

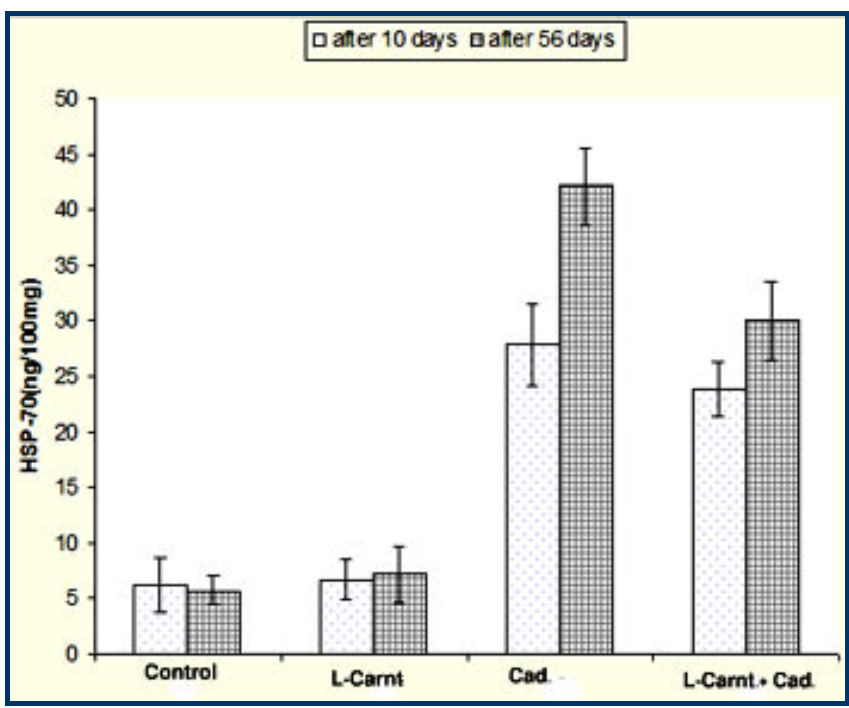

Figure 2: Elucidates that cadmium exposure induced significant elevations HSP70 in testis homogenates, either at 10 or 56 days post treatment. Meanwhile, simultaneous administration of cadmium chloride and L-Carnitine induce significant reduction of HSP70 in compare with cadmium chloride treated group. LCarnitine treated group didn't show any remarkable alterations in compare with control group.

\section{Heat shock proteins in different groups}

As Shown in Table 1 and figure $2, \mathrm{CdCl}_{2}$ treated rats (on days 10 and 56) induced significant elevations in HSP70 as compared to control (27.97 $\pm 3.7-42.11 \pm 3.4$ vs $6.31 \pm 2.4-5.68 \pm 1.3)$. Meanwhile, simultaneous administration of cadmium chloride and LCarnitine (on day 10 and 56) induced significant reduction in 
HSP70 as compared to cadmium chloride treated group (23.93 $\pm 2.5-30.11 \pm 3.5$ vs27.97 $\pm 3.7-42.11 \pm 3.4)$.

\section{Discussion:}

Cadmium is a ubiquitous environmental pollutant and it can affect human health through the food chain or via other approaches. As an example, heavy smoking is the commonest source human intake of cadmium that tends to accumulate in testis, and notably it has been associated with low sperm count and motility [33]. The accumulation and toxic effects of cadmium have attracted considerable attention. Previous studies have shown that testis is the target organ of cadmium and that cadmium can damage testicular tissue and reduce spermatogenesis [34, 35]. Kusakabe et al, using ELISA, have reported that low concentration $(2.5 \mu \mathrm{M})$ of cadmium doesn't induce DNA damage of rat Sertoli cells [35]. We found, using the single-cell gel electrophoresis (comet assay), that cadmium chloride exposure with $1.2 \mathrm{mg}$ produce significant elevations of tail moment in compare with control group as shown in Table 1 and Figure 1, the affected nuclei of comet tail are also shown in (Figures 3, 4). Cadmium uptake has been shown to be concentration-dependent due to an increase in active transepithelial ion transport [36]. Cadmium exposure produces reactive oxygen species (ROS) and results in the formation of denatured or abnormal proteins [37].

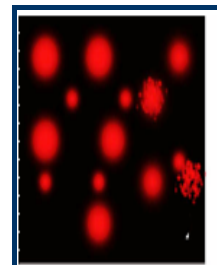

Control

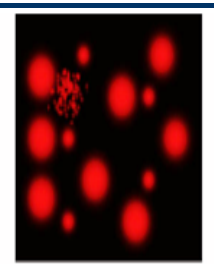

L-Carnitine

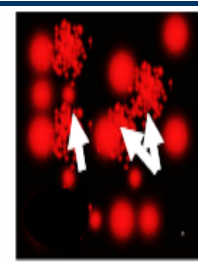

Cadmium

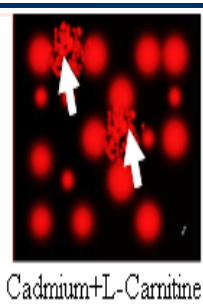

Cadmium+L-Carnitine
Figure 3: Demonstrates the effect of cadmium and L-Carnitine on DNA damage using comet assay after 10 days the white arrows pointed to comet tail of affected nuclei

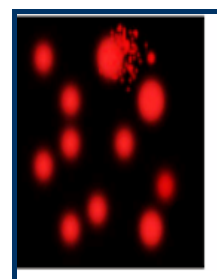

Control

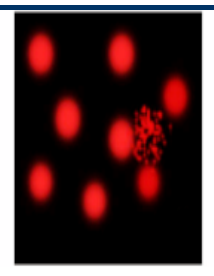

L-Carnitine

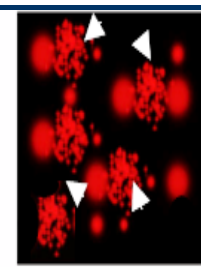

Cadmium

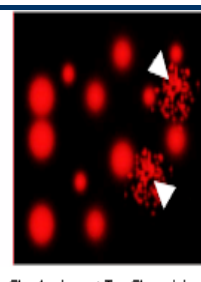

Cadmium+L-Carnitin
Figure 4: Demonstrates the effect of cadmium and L-Carnitine on DNA damage using comet assay after 56 days, the white arrows heads pointed to comet tail of affected nuclei

Another author's added cellular damage, such as DNA adducts, DNA strand breaks, chromosomal aberrations and the presence of micronuclei also occur following cadmium exposure [38]. The previous author added that relative amount of DNA damage is dependent on both the concentration of cadmium and the length of exposure [38]. However, cadmium not only induces DNA damage, but also interferes with DNA repair processes and enhances genotoxicity [37, 38]. Additionally, cadmium exposure also affects cellular calcium homeostasis and calcium-mediated functions in kidney cells by increasing intracellular calcium [36]. Changes in cell morphology are also observed, including an alteration of cell shape, a loss of cell-cell attachment and monolayer integrity, as well as disruption of actin filament distribution when treated with cadmium [36]. Going with the aforementioned results, it has been shown in this investigation that administration of cadmium chloride can exert DNA damage with increased duration to 56 days. Also, the level of $h s p 70$ increased with increasing duration of treatment to a maximum at 56 days of cadmium chloride treatment.In another study, both hsp30 and hsp70 mRNA accumulation increased with increasing duration of treatment from 8 to 16h, respectively, [39]. Further, enhanced synthesis of HSPs was demonstrated in mouse lymphocytes treated with elevated temperature plus ethanol [40].

The mechanism by which synergistic accumulation of HSPs was produced is not yet known; however, it could be explained by an increase in either the rate of transcription or stability of $h s p 70$ mRNA, or stability of their proteins [39].In this study, it was also plausible that cadmium stressor caused a significant increase in denatured or misfolded protein, thereby increasing the magnitude of Hsp70 response. This may be the case since cadmium affect protein structure through different means. Cd could induce DNA damage such as single- and double-strand breaks, modified bases, abasic sites, DNA-protein crosslink, and oxidized bases and even bulky adducts in organisms [41-43]. Our finding supports this claim that DNA damage detected by comet assay can be considered as a powerful biomarker assay in risk assessment of environmental pollutants like cadmium. In the present study, we anticipated noticing improvement in the testes cells after simultaneous administration of cadmium chloride and L-Carnitine that induce significant reduction of HSP-70 and tail moment in compare with cadmium chloride treated group. Carnitine, a branched non-essential amino acid, is synthesized from the essential amino acids lysine and methionine. Ascorbic acid, ferrous iron, pyridoxine and niacin are also necessary cofactors and deficiencies of any of these can lead to carnitine deficiency [44]. The pathway in mammals is unique using protein-bound lysine that is enzymatically methylated to form trimethyllysine as a post-translational modification of protein synthesis [44]. Trimethyllysine undergoes four enzymatic reactions in the course of endogenous L-Carnitine biosynthesis. One of the enzymes in this pathway, $\gamma$-butyrobetaine hydroxylase, is absent from cardiac and skeletal muscle but highly expressed in human liver, testes, and kidney [45]. In accordance with the previous information, our results revealed that that L-Carnitine treatment didn't exert any significant change on HSP70 level and the different parameters of DNA damage of rat's test homogenates in compare to control group throughout the whole experiment.

A study reported that benefits of carnitine are comparable with other drugs of choice in terms of effectiveness in preventing DNA damage to neural disorder [46]. Another study [47] suggested that L-Carnitine protection against the cytotoxicity of $\mathrm{Cd}$ may be related to the maintenance of normal redox balance inside the cell. L-Carnitine could exert a direct antioxidant action by the transport of long-chain fatty acids into the mitochondrial matrix, with subsequent increase in $\beta$-oxidation, acetyl-CoA and ATP production [48]. The testicular toxicity of cadmium appears to be mediated by a rapid apoptotic process as revealed by an increase in the number of TUNEL-positive 
cells in the seminiferous tubules of treated rats [49]. Our investigation showed that DNA damage level increased in the testes of the $\mathrm{CdCl}_{2}$-treated rats. The mechanism of $\mathrm{Cd}$-induced DNA base oxidation has not been fully elucidated. The available data indicates that $\mathrm{Cd}$ exposure induces oxidative DNA damage due to an excess of oxygen-derived free radicals [49]. Interestingly, the current work, however, is the first to show DNA damage-related increase HSPs-70after cadmium exposure in testis cells. And also the first to show protected DNA-related decrease in HSPs-70 in testis cells of rats after LCarnitine administration. Our findings that L-Carnitine administration to Cd-exposed rats minimized DNA damage in the rat testis could probably be related to its antioxidant proprieties [50] showed that L-Carnitine pretreatment can prevent testicular atrophy. In our study, the ability of LCarnitine to reduce the cytotoxicity of $\mathrm{Cd}$ in testis cells could be due to enhancing efflux of $\mathrm{Cd}$ and decreasing its accumulation in the nuclei of this target cell population in the rat testis and could be also through upregulation of HSP70. Another authors mentioned that L-Carnitine's ability to restore glutathione levels has broad implications beyond the obvious antioxidant benefit. They added that our bodies' glutathione status is intimately connected with the production of a special class of proteins whose function is to protect the structural and functional integrity of countless other proteins (which constitute most of the cellular machinery of life) from damage caused by such factors as excessive heat or cold, infection, inflammation, oxygen deprivation, cellular trauma, and toxic agents. The special proteins also protect against disruptions of redox homeostasis, the delicate balance between the oxidative and reductive (antioxidative) forces within our cells [47]. Carnitine has also been shown to modulate DNA damage and apoptosis by down-regulating proapoptotic Fas signals and suppressing the generation of ceramide, a key mediator of apoptosis [51].

Apoptosis is a consequence of a cascade of biochemical events, is encountered in all tissues and, characterized by blebbing of the plasmalemma, volume loss, condensation of the nucleus and lytic DNA degradation, ultimately leads to the programmed death of the cell. A key role in this process is played by the caspases, enzymes that cleave substrates once activated. Enhanced tissue levels of HSPs have been reported to inhibit intentionally induced apoptosis. For instance, in Hsp70overexpressing pulmonary endothelial cells, endotoxin-induced apoptosis is attenuated [52]. It is quite clear that induction of several members of the heat-shock protein family results in both acquired thermotolerance and decreased sensitivity to a broad range of cytotoxic stimuli [53]. HSP70 is the best studied of these proteins, and genetic studies have provided unambiguous support for HSP70 as a cytoprotective molecule [54]. Heat-shock proteins, including HSP70, can modify the antioxidant potential of cells. Although we did not perform traditional antioxidant experiments in the current study, recent data with stably transfected cell lines suggest an important antioxidant role for HSP70 [55]. These observations also provide support for the general concept that reactive oxygen intermediates play an important role in DNA degradation [56]. Although the role for reactive oxygen intermediates in DNA damage has been challenged [57], significant evidence exists to support this hypothesis; including an enhanced apoptotic response to a variety of stimuli in cells that under express enzymatic antioxidants [58]. Liu et al., suggest that cadmium, like other proapoptotic stimuli in other cells, generates reactive oxygen intermediates early in the course of apoptosis, providing kinetic support for the signaling potential of these free radicals. Thus HSP70 itself, or proteins modified by the induction of HSP-70 might reduce the accumulation of $\mathrm{Oi}$ immediately after exposure to cadmium and inhibit the ensuing process of DNA damage. In conclusion, $\mathrm{Cd}$ altered testicular function by inducing DNA damage, which could be reversed by administration of L-Carnitine suggesting the manipulation of HSP70 that may have clinical implications for the treatment of acute testis injury.

\section{Acknowledgements:}

This research project was supported by a grant from the research center of the Center for Female Scientific and Medical College in King Saud University.

\section{References:}

[1] Dalton TP et al. Proc Natl Acad Sci USA. 2005 102: 3401[PMID: 15722412]

[2] Bridges CC \& Zalups RK, Toxicol Appl Pharmacol 2005 204: 274[PMID: 15845419]

[3] Sittig M. Noyes Publications 1991.

[4] Prozialeck WC et al. Life Sci. 2006 79: 1493[PMID: 16765992]

[5] Valko M et al. Curr Med Chem. 2005, 12: 1161[PMID: 15892631]

[6] Hew KW et al. Biol Reprod. 1993 49: 840[PMID: 8218650].

[7] Hew KW et al. Toxicol Appl Pharmacol 1993 121: 15[PMID: 7687796]

[8] Wong CH et al. J Cell Sci. 2004 117: 783[PMID: 14734653].

[9] Prozialeck WC et al. Life Sci. 2006 79: 1493[PMID: 16765992]

[10] Mingrone G. Ann N Y Acad Sci. 2004 1033: 99[PMID: 15591007]

[11] Cave MC et al. Nutr Clin Pract 2008 23: 16[PMID: 18203961].

[12] Calabrese V et al. Antioxid Redox Signal 2010 13: 1763[PMID: 20446769].

[13] Rebouche CJ \& Seim H, Annu Rev Nutr 1998 18: 39[PMID: 9706218]

[14] Gramignano G et al. Nutrition 2006 22: 136[PMID: 16459226]

[15] Rossignol DA \& Frye RE, Mol Psychiatry 2011[PMID: 22143005]

[16] Hao J et al. Br J Nutr 2011 106: 648 [PMID: 21418712]

[17] Bowyer BA et al. Gastroenterology 1988 94: 434[PMID: 3121432]

[18] Karanth J \& Jeevaratnam K, Indian J Exp Biol. 2010 48: 503[PMID: 20795369]

[19] Romano $M$ et al. Dig Dis Sci. 2008 53: 1114[PMID: 17939042]

[20] Malaguarnera M et al. Am J Gastroenterol 2010 105: 1338[PMID: 20068559]

[21] Moradi Met al. Urol J. 2010 7: 188[PMID: 20845296].

[22] Kendler BS. Prev Med. 1986 15: 373[PMID: 3532087]

[23] De Vivo DC \& Tein I, Int Pediatr 1990 5: 8.

[24] Rebouche CJ. Ann N Y Acad Sci. 2004 1033: 30[PMID: 15591001]

[25] Rebouche CJ \& Chenard CA, J Nutr 1991 121: 539[PMID: 2007906] 
[26] Cave MC et al. Nutr Clin Pract. 2008 23: 16[PMID: 18203961]

[27] Ritossa FM. Ex.perientia. 1962 18: 571.

[28] Schlesinger MJ et al.Cold Spring Harbor. 1982.

[29] Tissières A et al. J Mol Biol. 1974 84: 389[PMID: 4219221]

[30] Nazan U et al. Neuroendocrinology. 2005 4: 121.

[31] Ates I et al. Biometals. 2004 17: 371[PMID: 15259357]

[32] Singh NP et al. Exp Cell Res. 1988 175: 184[PMID: 3345800]

[33] Thompson J \& Bannigan J, Reprod Toxicol 2008 25: 304 [PMID: 18367374]

[34] Kaisman ET et al. J Cell Physiol. 2009 220: 222[PMID: 19288494]

[35] Kusakabe $\mathrm{T}$ et al. Toxicol In Vitro. 2008 22: 1469[PMID:

[36] Bjerregaard H. Altern Lab Anim. 2007 35: 343[PMID: 17650953]

[37] Mouchet $\mathrm{F}$ et al. Environmental Toxicol. 2007 22: 422[PMID: 17607733]

[38] Mendez-Armenta M \& Rios C, Environ Toxicol Pharmacol. 2007 23: 350[PMID: 21783780]

[39] Heikkila JJ. J Cell Biochem. 2004 93: 672[PMID: 15389874]

[40] Rodenhiser DI et al. Can J Genet Cytol 1986 28: 1115[PMID: 3828898]

[41] Jimi S. Ann N Y Acad Sci. 2004 1011: 325[PMID: 15126309]

[42] Liu W et al. J Hazard Mater 2009 161: 878[PMID: 18502577] 18556172]

[43] Cenkci S et al. Chemosphere. 2009 76: 900[PMID: 19477479]

[44] Rebouche CJ. FASEB J. 1992 6: 3379[PMID: 1464372]

[45] Rebouche CJ \& Chenard CA, J Nutr 1991 121:539

[46] Traina G et al. Mol Neurobiol. 2008 38: 146 [PMID: 18726077]

[47] Koch A et al. Br J Nutr. 2007 98: 882[PMID: 17524183]

[48] Ishikura H et al. J Anal Toxicol 1996 20: 55[PMID: 8837953]

[49] Ates I et al. Biometals 2004 17: 371[PMID: 15259357]

[50] Zhou X et al. Asia Pac J Clin Nutr. 2007 16: 383[PMID: 17392136]

[51] Andrieu-Abadie N et al. FASEB J. 1999 13: 1501[PMID: 10463940]

[52] Wong HR et al. Am J Respir Cell Mol Biol. 1996 15: 745[PMID: 8969269]

[53] Minowada G \& Welch WJ. J Clin Invest. 1995 95: 3[PMID: 7814629]

[54] Vignola AM et al. Am J Respir Cell Mol Bioi. 1995 13: 683[PMID: 7576706]

[55] Simon MM et al. J Clin Invest. 1995 95: 926[PMID: 7883992]

[56] Buttke TM \& Sandstrom PA, Immunol Today. 1994 15: 7[PMID: 8136014]

[57] Jacobson MD \& Raff MC, Nature. 1995 374: 814[PMID: 7536895]

[58] Greenlung LJ et al. Neuron. 1995 14: 303[PMID: 7857640]

Edited by $\mathbf{P}$ Kangueane Citation: Selim et al. Bioinformation 8(1): 058-064 (2012) License statement: This is an open-access article, which permits unrestricted use, distribution, and reproduction in any medium, for non-commercial purposes, provided the original author and source are credited. 


\section{BIOINFORMATION}

\section{Supplementary material:}

Table 1: Shows that cadmium chloride treatment induced significant elevations of tailed cells, tail length, tail DNA \%, tail moments and HSP70 in compare to control group. Synchronized exposure to cadmium chloride and L-Carnitine induce significant reduction in DNA damage and HSP70 in compare to cadmium chloride treated group.

\begin{tabular}{|c|c|c|c|c|c|c|c|c|c|c|c|c|}
\hline \multirow{2}{*}{$\begin{array}{l}\text { Groups } \\
\text { Days }\end{array}$} & \multicolumn{2}{|c|}{ Tailed Cells\% } & \multicolumn{2}{|c|}{ Untailed Cells\% } & \multicolumn{2}{|c|}{ Tail length um } & \multicolumn{2}{|c|}{ Tail DNA\% } & \multicolumn{2}{|c|}{ Tail Moment } & \multicolumn{2}{|l|}{$\frac{\mathrm{HSP}-70}{\mathrm{ng} / 100 \mathrm{mg}}$} \\
\hline & 10 & 56 & 10 & 56 & 10 & 56 & 10 & 56 & 10 & 56 & 10 & 56 \\
\hline Control & $3 \pm 1.2$ & $\begin{array}{l}2.8 \pm 0 . \\
5\end{array}$ & $97 \pm 2.8$ & $\begin{array}{l}97.2 \pm 3 . \\
9\end{array}$ & $1.26 \pm 0.2$ & $1.38 \pm 0.3$ & $1.2 \pm 0.2$ & $1.27 \pm 0.4$ & $1.54 \pm 0.3$ & $1.77 \pm 0.1$ & $6.31 \pm 2.4$ & $5.68 \pm 1.3$ \\
\hline $\begin{array}{l}\text { L- } \\
\text { Carnitine }\end{array}$ & $3.6 \pm 1.1$ & $3 \pm 0.92$ & $96.4 \pm 4.28$ & $97 \pm 2.9$ & $1.42 \pm 0.4$ & $1.38 \pm 0.2$ & $1.34 \pm 0.3$ & $1.30 \pm 0.2$ & $1.39 \pm 0.4$ & $1.62 \pm 0.2$ & $6.73 \pm 1.8$ & $7.14 \pm 2.5$ \\
\hline Cad. Cl & $\begin{array}{l}15.32 \pm 4 . \\
7^{*}\end{array}$ & $\begin{array}{l}22 \pm 3.6 \\
*\end{array}$ & $\begin{array}{l}84.68 \pm 3.2 \\
*\end{array}$ & $78 \pm 4.0^{*}$ & $\begin{array}{l}4.98 \pm .0 .2 \\
*\end{array}$ & $\begin{array}{l}7.41 \pm 1.42 \\
*\end{array}$ & $\begin{array}{l}5.17 \pm 1.21 \\
*\end{array}$ & $\begin{array}{l}7.38 \pm 1.5 \\
*\end{array}$ & $\begin{array}{l}29.26 \pm 3.9 \\
*\end{array}$ & $\begin{array}{l}54.87 \pm 5.7 \\
*\end{array}$ & $\begin{array}{l}27.97 \pm 3.7 \\
*\end{array}$ & $\begin{array}{l}42.11 \pm 3.4 \\
*\end{array}$ \\
\hline $\begin{array}{l}\text { Cad.Cl+L } \\
- \\
\text { Carnitine }\end{array}$ & $13.6 \pm 4.2^{*}$ & $\begin{array}{l}17 \pm 3.5 \\
*\end{array}$ & $86.4 \pm 4.7^{*}$ & $83 \pm 3.5^{*}$ & $4.37 \pm 0.3^{*}$ & $\begin{array}{l}5.67 \pm 1.33 \\
*\end{array}$ & $4.69 \pm 1.0^{*}$ & $\begin{array}{l}5.53 \pm 0.3 \\
*\end{array}$ & $\begin{array}{l}22.24 \pm 2.7 \\
*\end{array}$ & $\begin{array}{l}31.40 \pm 3.5 \\
*\end{array}$ & $\begin{array}{l}23.93 \pm 2.5 \\
*\end{array}$ & $\begin{array}{l}30.11 \pm 3.5 \\
*\end{array}$ \\
\hline
\end{tabular}

* Significant at $\mathrm{p}<0.05$. 